\title{
Long-term home use of dobutamine in end-stage heart failure in Nigeria: A case report and review of literatures
}

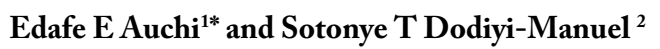 \\ ${ }^{1}$ Department of Internal Medicine, Niger Delta University, Amassoma, Nigeria \\ ${ }^{2}$ University of Port Harcourt Teaching Hospital, Port Harcourt, Nigeria
}

\begin{abstract}
Introduction: Dobutamine increases cardiac contractility and causes vasodilation with little change in heart rate. It used in the management of acute heart failure with cardiogenic shock or in patients with low blood pressure. It has also been documented for use in the management of chronic heart failure. We reported an 86-year-old man with a refractory heart on long term dobutamine.

Case Summary: An 86-year-old retired civil servant living with hypertension for 26 years, type 2 Diabetes Mellitus (T2DM) for 14 years, and hyperlipidemia for 10 years. He was diagnosed with biventricular failure 6 years ago and had cardiac resynchronization therapy (CRT-D) implanted 4 years before the presentation. He presented to the emergency department with 6 weeks history of bilateral leg swelling, dyspnea, orthopnea, paroxysmal nocturnal dyspnea, and oliguria. He has more than 12 repeated hospital admissions for heart failure in the past 4 years despite having CRT-D. He was noted to be anxious and diaphoretic with a respiratory rate of 36 breaths/minute, blood pressure of $84 / 52 \mathrm{~mm} \mathrm{Hg}$, heart rate 80 beats/minute. Peripheral pulses were threatened and diminished in amplitude, and his hands and feet were cool and moist. A summation gallop was noted over the precordium. Fine crepitations were heard over the posterior-basal regions of both lungs. The electrocardiogram showed pacemaker rhythms. He was treated for NYHA class IV heart failure with digoxin, and dobutamine and furosemide. He was discharged home on long term dobutamine infusion.
\end{abstract}

Conclusion: Home dobutamine is a simple and effective in term treatment for end-stage heart failure. Its widespread use may be restricted by cost and expertise considerations in Nigeria

\section{Background}

Dobutamine increases cardiac contractility and causes vasodilation with little change in heart rate [1,2]. It is routinely administered for short periods to relieve exacerbations of congestive heart failure (CHF) in hospitalized patients [3-5]. Sustained effects have been seen with dobutamine infusions, although the known properties of the drug do not explain these effects [6,7]. Long-term dobutamine therapy could lessen the symptoms of $\mathrm{CHF}$ and improve exercise tolerance and cardiac function $[2,4]$. It could be used in patients with refractory heart failure and that awaiting heart transplantation. It also benefits patients with contra-indication to heart transplantation [2,4]. Because the therapy has not been shown to prolong survival in most patients, specific endpoints of therapy could be determined for each patient. Because it may cause sudden death, patients receiving this therapy must be carefully monitored. Long-term use of dobutamine infusion lessens the symptoms of CHF has not been shown to prolong survival but it reduces frequency of hospital admission $[4,5]$.

Outpatient dobutamine infusion for heart failure has not come into a routine practice and prescription in Nigeria medical practice. However, the world being a global village, many of our heart failure patients now travel oversea to seek more advanced medical care in other countries outside Nigeria. They return home after a brief stay of managing the acute condition in those hospitals. At home in Nigeria, they would present to the physicians for continue follow up. Hence, we report this case with review of literature that been on long-term home use of dobutamine in end-stage heart failure from our facility outpatient department in Nigeria.

\section{Case presentation}

An 86-year-old retired civil servant who had been living with hypertension for 26 years, type 2 Diabetes Mellitus (T2DM) for 14 years and hyperlipidemia for 10 years. He was diagnosed with biventricular failure 4 ago and had cardiac resynchronization therapy (CRT-D) implanted 3 years ago in a hospital in the United States of America. He presented to the emergency department with 6 weeks history of recurrent bilateral leg swelling with associated dyspnea, orthopnea, paroxysmal nocturnal dyspnea, and oliguria. He has more than 12 repeated hospital admission for heart failure in the past 4 years after the CRT-D. He continued to be admitted every 2 to 3 with gross leg edema, acute pulmonary edema, hypotension, and angina.

At the emergency room, he was noted to be anxious and diaphoretic with a respiratory rate of 36 breaths/minute, not pale, anicteric, no digital clubbing, and bilateral leg edema up to the mid-shin. The chest showed bilateral crepitation in both lung lungs zones. Pulse was 102 beats/minute (diminished in amplitude, and his hands and feet were cool and clammy), blood pressure of $84 / 50 \mathrm{~mm} \mathrm{Hg}$. His jugular venous pressure was elevated at $12 \mathrm{~cm} \mathrm{H}_{2} \mathrm{O}$. A summation gallop ( $\mathrm{S} 1, \mathrm{~S} 2$ and $\mathrm{S} 3$ ) was noted over the precordium. Finger and ear pulse oxygen saturation

${ }^{\star}$ Correspondence to: Edafe Emmanuel Auchi, Department of Internal Medicine, Niger Delta University, Amassoma, Nigeria, E-mail: dremmanueledafe@gmail.com

Key words: Dobutamine, refractory heart failure, long term use, home

Received: April 17, 2020; Accepted: April 24, 2020; Published: April 30, 2020 
was $80 \%$ on room air and $96 \%$ on $4 \mathrm{~L} / \mathrm{min}$ via nasal cannula. The serum sodium $124 \mathrm{mmol} / \mathrm{l}$, potassium $3.9 \mathrm{mmmol} / \mathrm{l}$, urea $15 \mathrm{mmol} / \mathrm{l}$ (3.2-9 $\mathrm{mmol} / \mathrm{l})$, creatine $350 \mathrm{umol} / \mathrm{l}$. The electrocardiogram showed a pacemaker rhythm. The echocardiography showed an ejection fraction of $28 \%$, dilated four chambers.

Dobutamine $(8 \mathrm{mcg} / \mathrm{kg} / \mathrm{min})$, sub-cutaneous clexane $(0.4 \mathrm{mls})$, and digoxin $(0.125 \mathrm{mg})$ daily were initially commenced. The blood pressure improved and sustained in the ranged of systolic $(120-130 \mathrm{mmHg})$ and diastolic $(80-90 \mathrm{mmHg}$ ) on dobutamine. Furosemide $80 \mathrm{mg}$ twice daily was added to the treatment when his blood pressure improved. Dobutamine was later maintained at a dose of $5 \mu \mathrm{g} / \mathrm{kg} /$ minute, with improvement in cardiac output and consequent diuresis. Any attempt to wean him off dobutamine, his clinical condition worsened. $\mathrm{He}$ continued on infusion rate with the diluted drug in a dose of $2000 \mathrm{mg}$ in $500 \mathrm{mls}$ of $5 \%$ Dextrose water and run $125 \mathrm{mls}$ per day at a rate of 5 drops per minute from Moog Curlin infusion Pump (Curlin Medical) via a Bard pink peripheral venous line with an inline bacterial filter (Figures 1-5). He was discharged self-caring with help from his general practitioner and a nurse. At discharge, he was advised to continue on subcutaneous Lantus 30 IU for his diabetes control, oral metoprolol succinate $50 \mathrm{mg}$ daily, oral spironolactone $25 \mathrm{mg}$ daily, oral furosemide $60 \mathrm{mg}$ twice daily, oral digoxin $0.125 \mathrm{mg}$ daily and regular check of his CRTD.

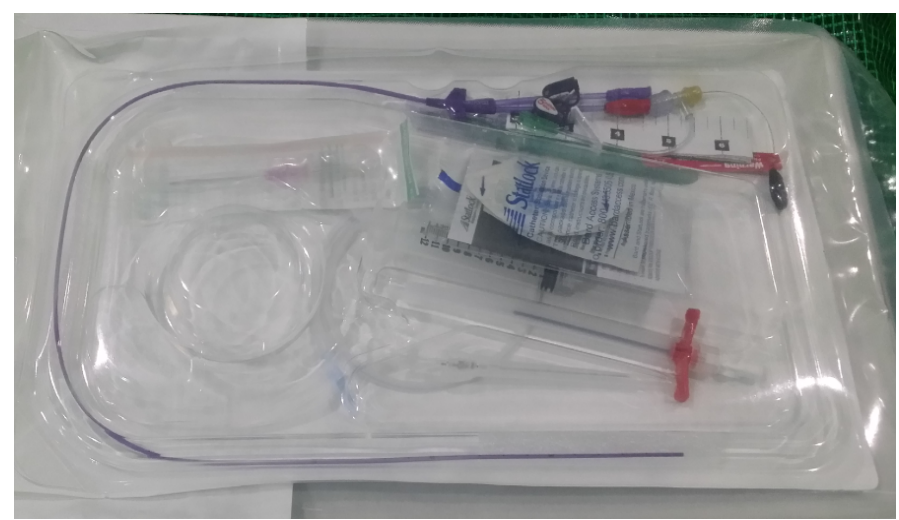

Figure 1. Two-way pink peripheral line set.

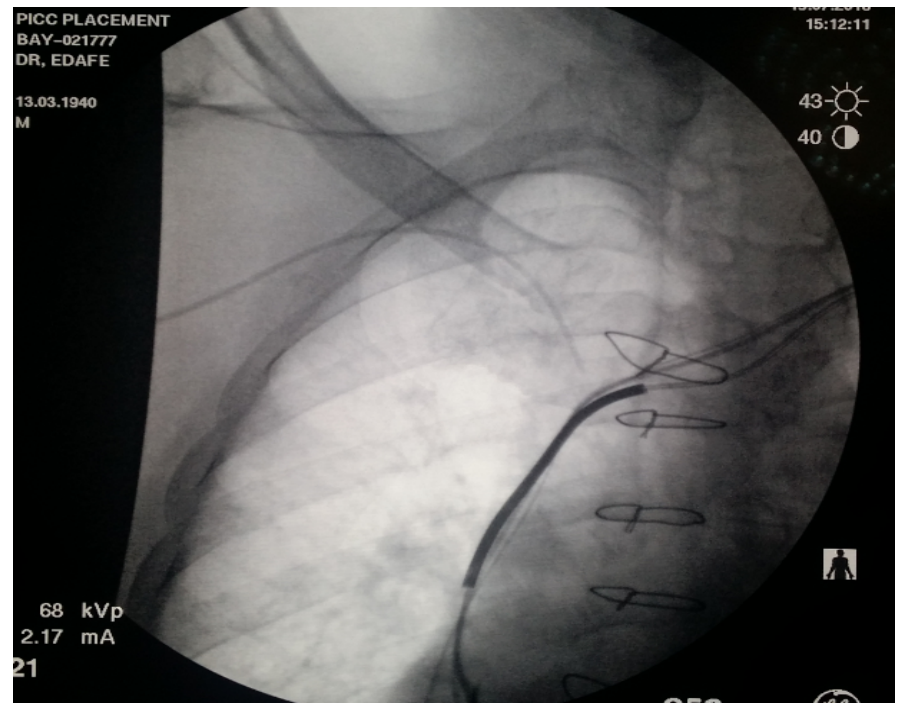

Figure 2. The peripheral line showed on fluoroscopy from the right basilic vein to the right subclavan vein. The arrow showed the end of the pink line.

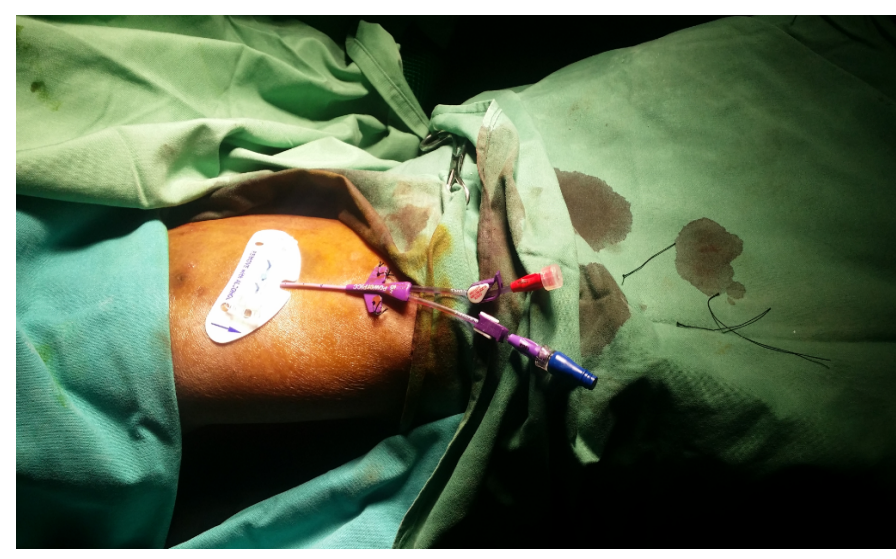

Figure 3. 5F pink peripheral line in situ through the right basilica vein

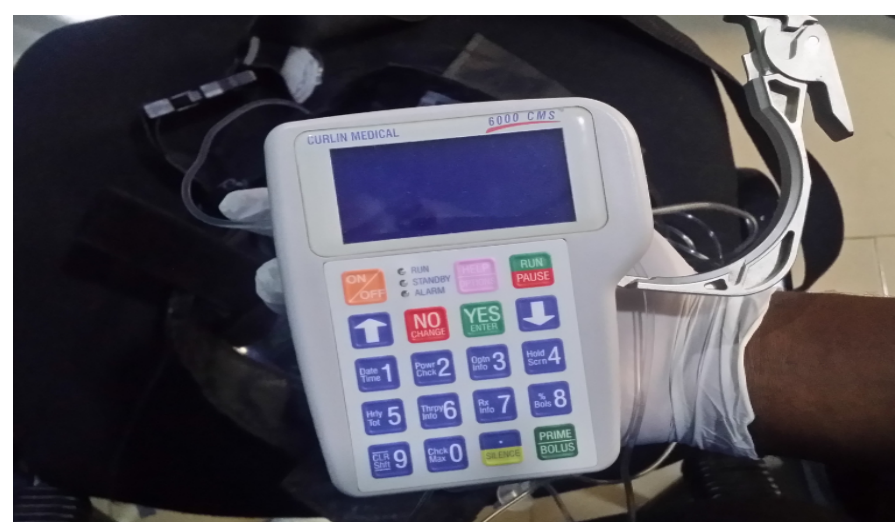

Figure 4. Dobutamine infusion machine

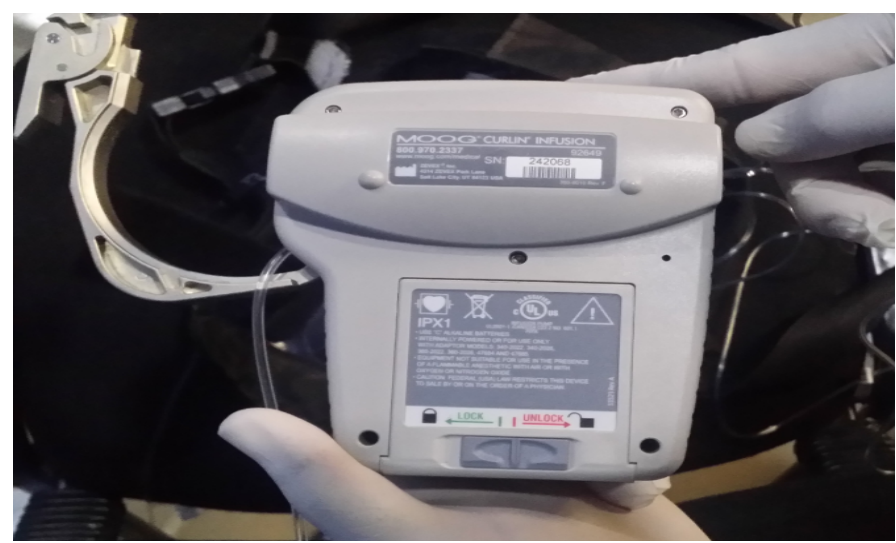

Figure 5. Dobutamine infusion machine

\section{Follow up}

Two months later he was content with his quality of life and able to walk from a car and return to his usual business. He continued to receive continuous dobutamine infusion for over 8 Months with no thrombotic infective complications of treatment with sustained clinical improvement. He has been carrying out his official and home function with no episodes of pulmonary edema or worsening of his heart failure. There has been improvement in exercise tolerance and quality of life, and freedom from hospital admission. Functional improvement from NYHA 4 to 2 in four months.

The patient has been on home dobutamine infusion via a pink peripheral line inserted through the right basilic vein for 7 months. 
The peripheral pink link line was changed after 7 month and no complication noted. This home based dobutamine infusion continued till the $9^{\text {th }}$ month when he stated having deterioration in heart failure back to stage 4 NYHA. This he battled with for another 3 months before he died of cardiopulmonary collapse.

\section{Discussion}

Dobutamine is a member of the catecholamine family of adrenergic agents. It was formulated to augment ventricular systolic function [812 ]. Dobutamine acts principally through stimulation of $\beta 1$-adrenergic receptors with lesser stimulation of $\beta 2$ - and $\alpha$-adrenergic receptors $[10,11]$. Therefore, dobutamine enhances ventricular contraction with little net direct effect on peripheral vasculature $[10,11]$. In the setting of human heart failure, the cardiac $\beta 1$-adrenergic receptors are generally down regulated from chronic stimulation (elevated circulating catecholamines) or blocked by $\beta 1$-selective adrenergic blockers; most of dobutamine's hemodynamic effects are then most likely rendered through $\beta 2$-adrenergic stimulation In states of ventricular systolic dysfunction, dobutamine increases contractility, stroke volume, and cardiac output $[10-11,13]$.

In the clinical setting with reduced ventricular systolic function, filling pressures, reduced stroke volume and cardiac output, and systemic and organ hypoperfusion, dobutamine increases stroke volume, cardiac output, systemic pressure, and systemic and organ perfusion, and reduces ventricular filling pressures and systemic and pulmonic vascular resistances [10,11,13-16]. Our patient was on Dobutamine to improve the contractility and renal perfusion. Proper dose selection and increamentation achieve these favorable responses without significantly increasing heart rate or provoking other adverse effects [13-14,17-18]. Our patient has not reported any adverse effect of the Dobutamine. He continued till the $9^{\text {th }}$ month at home before the symptoms started deteriorating. He finally passed from cardiopulmonary collapse. The relatively wide separation of positive inotropic and chronotropic effects is an ideal pharmacologic property of an agent intended for short-term therapy of systolic cardiac failure, but this wide separation cannot be maintained for dobutamine if the initial dose is too high [17-20].

Dobutamine also has a favorable effect on ventricular diastolic properties and on ventricular-vascular coupling by reducing aortic impedance [16]. As a positive inotropic agent, dobutamine increases myocardial oxygen consumption [14]. In human low-output cardiac failure, the patient substrate for dobutamine use, this agent increases enterohepatic, renal, and limb blood flow proportional to the augmentation in cardiac output [21-28]. Our patient had better renal perfusion with improvement in urine output, leg edema and reduced hospital admission.

At Ohio State University, long-term dobutamine therapy (typically 5.0-7.5 micrograms $/ \mathrm{kg} / \mathrm{min}$ infused continuously) is used in patients with refractory CHF and that awaiting heart transplantation [29]. Our patient had CRT-D implantation, yet heart failure symptoms persist, and he continued in the part of deterioration and frequent hospital admission before the introduction of long term dobutamine in his management. This necessitates the use of dobutamine infusion. Because the therapy does not prolong survival in most patients, he has benefitted with less hospital admission in the past 8 months. Because it may cause sudden death, patients receiving this therapy must be carefully monitored. Long-term use of dobutamine infusion lessens the symptoms of CHF but does not prolong survival [24-27]. Our patient was on guideline-directed medical therapy and CRTD. Yet, his heart failure continues to deteriorate. In Nigeria, no center is currently offering heart transplantation. Ventricular assist devices such as Tandem Heart and Extracorporeal membrane oxygenation (ECMO) are not available. Our patient has been out of hospital admission for about 8 months while on long term dobutamine infusion.

The main argument against continuous home dobutamine infusion is financial. The drug alone in our case costs approximately 70 thousand naira per week, with other charges for lines, $5 \% \mathrm{D} / \mathrm{W}$, and syringes plus a degree of home supervision and maintenance of the line. Our patient was able to afford it. The pink peripheral line was changed in our facility under ultrasound guidance and fluoroscopy in a procedure that lasted for 15 to 20 mines under local anesthesia. Our patient was saved from protracted hospital hospitalization

\section{Conclusion}

Home dobutamine is a simple and effective in term treatment for end-stage heart failure. Its widespread use may be restricted by cost and expertise considerations in Nigeria.

\section{Declaration of patient consent}

The authors certify that they have obtained all appropriate patient consent forms. In the form the patient(s) has/have given his/her/their consent for his/her/their images and other clinical information to be reported in the journal. The patients understand that their names and initials will not be published and due efforts will be made to conceal their identity, but anonymity cannot be guaranteed.

\section{Financial support and sponsorship}

Nil.

\section{Conflict of interest}

$$
\text { Nil. }
$$

\section{References}

1. Leier CV, Unverferth DV, Kates RE (1979) The relationship between plasma dobutamine concentrations and cardiovascular responses in cardiac failure. $\mathrm{Am} \mathrm{J} \mathrm{Med}$ 66: 238-242. [Crossref]

2. Applefeld MM, Newman KA, Grove WR, Sutton FJ, Roffman DS, et al. (1983) Intermittent, continuous outpatient dobutamine in the management of congestive heart failure. Am J Cardiol 51: 455-458. [Crossref]

3. Collins JA, Skidmore MA, Melvin DB, Engel PJ (1990) Home intravenous dobutamine therapy in patients awaiting heart transplantation. J Heart Transplant 9: 205-208. [Crossref]

4. Miller LW, Merkle EJ, Herrmann V (1990) Outpatient dobutamine for end-stage congestive heart failure. Crit Care Med 18: S30-S33. [Crossref]

5. Roffman DS, Appelfeld MM, Grove WR, Talesnick BS, Sutton FJ, et al. (1985) Intermittent dobutamine hydrochloride infusions in outpatients with chronic congestive heart failure. Clin Pharm 4: 195-199. [Crossref]

6. Goldstein RA, Passamani ER, Roberts R (1980) A comparison of digoxin and dobutamine in patients with acute infarction and cardiac failure. $N$ Engl J Med 303: 846-850. [Crossref]

7. Francis GS, Sharma B, Hodges M (1982) Comparative hemodynamic effects of dopamine and dobutamine in patients with acute cardiogenic circulatory collapse. $\mathrm{Am}$ Heart J 103: 995-1000. [Crossref]

8. Tuttle RR, Mills J (1975) Dobutamine: development of a new catecholamine to selectively increase cardiac contractility. Cir Res 36: 185-196.

9. Williams RS, Bishop T (1981) Selectivity of dobutamine for adrenergic receptor subtypes: in vitro analysis by radioligand binding. J Clin Invest 67: 1703-1711. [Crossref]

10. Ruffolo RR Jr (1987) The pharmacology of dobutamine. Am J Med Sci 294: 244-248. [Crossref] 
11. Jewitt D, Mitchell A, Birkhead J, Dollery C (1974) Clinical cardiovascular pharmacology of dobutamine a selective inotropic catecholamine. The Lancet 304: 363-367. [Crossref]

12. Beregovich J, Bianchi C, D'Angelo R, Diaz R, Rubler S (1975) Haemodynamic effects of a new inotropic agent (dobutamine) in chronic cardiac failure. Br Heart J 37: 629634. [Crossref]

13. Akhtar N, Mikulic E, Cohn JN, Chaudhry MH (1975) Hemodynamic effect of dobutamine in patients with severe heart failure. Am J Cardiol 36: 202-205. [Crossref]

14. Leier CV, Webel JA, Bush CA (1977) The cardiovascular effects of the continuous infusion of dobutamine in patients with severe cardiac failure. Circulation 56: 468-472. [Crossref]

15. Andy JJ, Curry CL, Ali N, Mehrotra PP (1977) Cardiovascular effects of dobutamine in severe congestive heart failure. Am Heart J 94: 175-182.

16. Little WC, Rassi A, Freeman GL (1987) Comparison of effects of dobutamine and ouabain on left ventricular contraction and relaxation in closed-chest dogs. J Clin Invest 80: 613-620. [Crossref]

17. Carroll JD, Lang RM, Neumann AL, Borow KM, Rajfer SI (1986) The differential effects of positive inotropic and vasodilator therapy on diastolic properties in patients with congestive cardiomyopathy. Circulation 74: 815-825. [Crossref]

18. Parker JD, Landzberg JS, Bittl JA, Mirsky I, Colucci WS (1991) Effects of betaadrenergic stimulation with dobutamine on isovolumic relaxation in the normal and failing human left ventricle. Circulation 84: 1040-1048. [Crossref]

19. Binkley PF, Van Fossen DB, Nunziata E, Unverferth DV, Leier CV (1990) Influence of positive inotropic therapy on pulsatile hydraulic load and ventricular-vascular coupling in congestive heart failure. J Am Coll Cardiol 15: 1127-1135. [Crossref]

20. Bendersky R, Chatterjee K, Parmley WW, Brundage BH, Ports TA (1981) Dobutamine in chronic ischemic heart failure: alterations in left ventricular function and coronary hemodynamics. Am J Cardiol 48: 554-558. [Crossref]
21. Pozen RG, Dibianco R, Katz RJ, Bortz R, Myerburg RJ, et al. (1981) Myocardial metabolic and hemodynamic effects of dobutamine in heart failure complicating coronary artery disease. Circulation 63: 1279-1285. [Crossref]

22. Meyer SL, Curry GC, Donsky MS, Twieg DB, Parkey RW, et al. (1976) Influence of dobutamine on hemodynamics and coronary blood flow in patients with and without coronary artery disease. Am J Cardiol 38: 103-108. [Crossref]

23. Beanlands RS, Bach DS, Raylman R, Armstrong WF, Wilson V, et al. (1993) Acute effects of dobutamine on myocardial oxygen consumption and cardiac efficiency measured using carbon-11 acetate kinetics in patients with dilated cardiomyopathy. $J$ Am Coll Cardiol 22: 1389-1398. [Crossref]

24. Magorien RD, Unverferth DV, Brown GP, Leier CV (1983) Dobutamine and hydralazine: comparative influences of positive inotropy and vasodilation on coronary blood flow and myocardial energetics in nonischemic congestive heart failure. $J \mathrm{Am}$ Coll Cardiol 1: 499-505. [Crossref]

25. Leier CV, Heban PT, Huss PA, Bush CA, Lewis RP (1978) Comparative systemic and regional hemodynamic effects of dopamine and dobutamine in patients with cardiomyopathic heart failure. Circulation 58: 466-475. [Crossref]

26. Barbato E, Bartunek J, Wyffels E, Wijns W, Heyndrickx GR, et al. (2003) Effects of intravenous dobutamineon coronary vasomotion in humans. $J$ Am Coll Cardiol 42 : 1596-1601. [Crossref]

27. Burger AJ, Horton DP, LeJemtel T, Ghali JK, Torre G, et al. (2002) Effect of nesiritide (B-type natriuretic peptide) and dobutamine on ventricular arrhythmias in the treatment of patients with acutely decompensated congestive heart failure: the PRECEDENT study. Am Heart J 144: 1102-1108. [Crossref]

28. Abraham WT, Adams KF, Fonarow GC, Costanzo MR, Berkowitz RL, et al. (2005) In-hospital mortality in patients with acute decompensated heart failure requiring intravenous vasoactive medications: an analysis from the Acute Decompensated Heart Failure National Registry (ADHERE). J Am Coll Cardiol 46: 57-64. [Crossref]

29. Pickwork KK (1992) Long-term dobutamine therapy for refractory congestive hear failure. Clin Pharm 11: 618-624. [Crossref]

Copyright: (C2020 Auchi EE. This is an open-access article distributed under the terms of the Creative Commons Attribution License, which permits unrestricted use, distribution, and reproduction in any medium, provided the original author and source are credited. 